\title{
Advancing recovery and cryopreservation of rat spermatogonia for germ stem cell banking
}

\author{
T. L. Syvyk ${ }^{1}$, L. S. Djachenko ${ }^{1}$, A. E. Syvyk ${ }^{2}$ \\ ${ }^{1}$ Bila Tserkva National Agrarian University \\ 8/1, Soborna Sq., Bila Tserkva, Ukraine, 09117 \\ ${ }^{2}$ Blinn College 902 College Ave, \\ Brenham, USA, 77833 \\ dr.syvyk@hotmail.com
}

\begin{abstract}
Aim. Optimisation of spermatogonial cryopreservation medium and spermatogonia recovery procedures essential for the male germ cell research and spermatogonia mediated transgenesis in rodents. Methods. PCR, LIVE/DEAD ${ }^{\circledR}$ Cell Viability Assays, Spermatogonial Colony Forming Assay, immunocytochemistry, cryopreservation and thawing spermatogonia cells. Results. Three Sleeping Beauty mutant spermatogonia stem cell lines were stored in liquid nitrogen, after 17-24 months of cryopreservation, were derived in parallel from recovered cryopreserved cultures via an established laminin selection procedure and by an alternative method termed as direct SG (Spermatogonia Growth) medium selection on MEFs (mouse embrionic fibroblasts). A spermatogenic potential of the cell lines derived by these two methods was verified by the spermatogonia transplantation in vivo and reestablishing the mutant animal lines. We optimized the concentration of DMSO in a freezing medium for spermatogonial cell lines. Conclusions. We developed and optimized recovery of spermatogonial stem cells, that could be consistently derived from the freshly thawed stocks of testicular cells cryopreserved in SG medium. Our data suggest that the $8 \%$ DMSO is the most effective concentration of the cryoprotectant in SG medium.
\end{abstract}

Ke y w o r d s: spermatogonia stem cell, mutant lines, laminin selection, cryopreservation.

\section{Introduction}

The study on spermatogenesis is advanced due to the ability to isolate, maintain, preserve, recover and transplant spermatogonial stem cells from different species [1-3]. There are three main methods developed for isolation of primary culture of spermatogonia from the variety of species based on different principals and their combinations: magnetic or fluorescent cell sorting based on surface markers [4]; density gradient centrifugation [5]; and differential adhesion selection [6]. The spermatogonia stem cell lines could be derived from the

(C) 2018 T. L. Syvyk et al.; Published by the Institute of Molecular Biology and Genetics, NAS of Ukraine on behalf of Biopolymers and Cell. This is an Open Access article distributed under the terms of the Creative Commons Attribution License (http://creativecommons.org/licenses/by/4.0/), which permits unrestricted reuse, distribution, and reproduction in any medium, provided the original work is properly cited 
obtained primary culture of testicular cells and maintained for a prolonged time. Cell lines could be cultivated in the medium containing serum from as low as $1 \%$ to as high as $20 \%$. The presence of serum in the medium can stimulate not only the growth of the somatic cells but also drive the differentiation of the germ cells by serum factors yet to be identified $[7,8]$. We developed a serum-free Spermatogonial Growth medium (SG medium) able to support continuously the proliferation of rat spermatogonial stem cells and maintain their spermatogenic potential upon transplantation into recipient testis [9]. This medium does not support the division of somatic cells and proliferation of differentiated germ cells which is advantageous for the spermatogonial stem cell line establishment.

A robust and reproducible methodology for the primary culture preparation and storage with subsequent line derivation is needed. It is especially important when large-scale projects, such as mutant line generation, involve a large number of samples that can be collected and deposited to cryo-banks of frozen spermatogenic cell lines. Successful recovery of the mutant cell lines and ultimate reestablishment of the animal line are of paramount importance for any research project and for generation of mutant libraries especially $[10,11]$. The spermatogonial cell lines could be recovered from cryopreserved cultures and transplanted into an appropriate recipient for the reestablishment of mutant animal lines upon request $[3,12]$. For this purpose, we thawed several previously frozen collagen-none-binding primary spermatogenic cell cultures and applied a standard sequential differential adhesion selection on laminin and collagen-coated plates for initiation of the selected spermatogonial stem cell lines. This method was compared to a direct SG medium selection on MEFs without any preliminary differential adhesion selection. The cells derived by both methods were transplanted into the recipient males and the effectiveness of the mutant animal lines reestablishment was compared by estimation of the number of obtained mutant animals $[10,13]$.

For cryopreservation of abovementioned cultures, we used our standard SG medium supplemented with $10 \% \mathrm{v} / \mathrm{v}$ DMSO which is the most widely accepted dosage of this intracellular cryoprotectant for a broad range of cell types $[10,14]$. Such situation requires experimental adjustment of the dose of the main cryoprotectant for each cell type. Since such experimental adjustment for rat spermatogenic cell has been never done before we decided to cover this gap and test a range of DMSO concentration in the SG based freezing medium for freshly prepared spermatogonial cell cultures.

\section{Materials and Methods}

\section{Animals lines, Care and Use}

All of the protocols for use of animals in this study were approved by the IACUC at the University of Texas Southwestern Medical Center at Dallas as certified by the Association for Assessment and Accreditation of Laboratory Animal Care International (AALAC). Rats were kept in individually ventilated cages (Lab Products 2100) in dedicated facilities with climate control set to $22{ }^{\circ} \mathrm{C}$, and $50 \%$ humidity. Animals were kept under a 12/12 hours light/dark cycle with lights on at 6 a.m. and 
off at 6 p.m. Wildtype Sprague Dawley rats were from Harlan, Inc., and used previously to generate SD-Tg(ESptd1-EGFP) rats; SDTG(SB-Tmx4tg;wt), SD-TG(SB-Gsg11 1t; wt), SDTG(SB-Slc35a3 $3^{\text {tg; } w t), ~ S D-T G(S B P a n ~} 3^{\text {tg; }}{ }^{\text {t }}$ ), SD-TG(SB-Zmynd8 ${ }^{\text {tg; }}$ (wt) rats [11].

Derivation of mutant cell lines and reestablishment of mutant animal lines from frozen primary culture of collagen-nonebinding spermatogenic cells

The collagen-none-binding spermatogenic cells were isolated from 22-23 day old rats harboring Sleeping Beauty transposon $\beta$-geo traps in Tmx4, Pan3, Slc35a3, Zmynd8 and Gsg11 by the method described previously [10, 11]. Isolated plastic and collagen predominantly spermatogenic cell population from each animal line was resuspended in ice-cold Spermatogonia Freeze Medium (SG medium plus $10 \% \mathrm{v} / \mathrm{v}$ of DMSO) aliquoted in cryovials by $1 \mathrm{ml} / \mathrm{vial}$ at average $3-3.5 \times 10^{6} \mathrm{cell} / \mathrm{ml}$. After $\sim 16-24$ months of cryostorage two vials with collagen-none-binding cells from each mutant line were thawed. Cellular pellets were suspended in SG Medium and then pooled into a single tube. Cell suspensions were divided into two equal parts. One part underwent an established laminin matrix selection procedure in duplicate laminin-coated wells $\left(\sim 3.8 \mathrm{~cm}^{2}\right)$ for $\sim 40$ min before being harvested and incubated overnight on one gelatin-coated well $\left(\sim 9.5 \mathrm{~cm}^{2}\right)$ /strain for 16-24 hours, as described [10]. After selection on gelatin, the cells were harvested and then plated on irradiated DR4 Mouse Embryonic Fibroblasts (Bio Pioneer Inc.) in duplicate wells $\left(\sim 1.9 \mathrm{~cm}^{2}\right)$ to initiate the subculture of spermatogonial lines [10]. The second half of the thawed cells dispersed in SG medium was plated onto a single well $\left(\sim 9.5 \mathrm{~cm}^{2}\right)$ of irradiated DR4 MEFs without selection on extracellular matrices. This second approach we termed the direct SG selection on MEFs or in short - SG selection. The cells were passed every 11-12 days onto a fresh monolayer of MEFs at (1-3) $\times 10^{4} \mathrm{cells} / \mathrm{cm}^{2}$. Total cell yield of established spermatogonial stem cell line derived with these two methods was compared during every passage. Spermatogonia were sub-cultured over 6-7 passages and then the cells from respective lines were transplanted into testes of busulfantreated, Sprague Dawley rats at $\sim 3.5 \times 10^{5}$ cells/ testis to evaluate their sperm forming potential by visualization of the tgGCS-EGFP transgene in recipient testes, or by mating with wildtype females between days 65-300 post-transplantation $[10,15]$. The progeny were genotyped using gene specific PCR primers in combination with primers unique to the Sleeping Beauty transposon construct [11].

\section{Cryopreservation and thawing Spermatogonia}

Spermatogonial Growth Freezing Medium (SG Freezing Medium) was prepared by adding $10 \%$ of DMSO (v/v) (D2650, Sigma, Inc.) to filter sterilized SG Medium as a standard preparation $[14,16]$. SG Freezing Medium with $10 \%$ of DMSO was used as a control. Experimental SG freezing mediums contained following doses of DMSO $(6 ; 8 ; 12 ; 14 ; 16$; $18 \%$ v/v). Prepared SG Freezing Media were stored at $-20^{\circ} \mathrm{C}$ in $5 \mathrm{ml}$ aliquots for no longer than one month. After thawing the unused Freezing medium was discarded. Specified number of cells from cell lines or from freshly isolated spermatogenic cultures were spun 
down at $400 \mathrm{Xg}$ for $5 \mathrm{~min}$ and the supernatant was carefully removed. The cells were resuspended by gentle pipetting in $1 \mathrm{ml}$ volume of SG Freezing Medium. Cell suspension was immediately transferred to the pre-labeled chilled cryovials (cat. No. 03-337-7D, Thermo Fisher Scientific Nalgene, Inc.) and placed on ice while finishing aliquots. Cryovials were then rapidly transferred into the 5100 Cryo $1{ }^{\circ} \mathrm{C}$ Freezing Container "Mr. Frosty" (cat. No. 15-350-50, Thermo Fisher Scientific Nalgene, Inc.). After freezing at $-80^{\circ} \mathrm{C}$ for 48 hours the cryovials were transferred into the $\mathrm{S} 3000-\mathrm{AB}$ Standard Liquid Nitrogen Freezer (Custom BioGenic System $($ ) for long term storage. Thawing of the cryopreserved cells was conducted, as described [16]. Hemacytometer (cat. No. 02-671-6, Fisher, Inc.) was used to count the cells and estimate the number of the viable cells by Trypan Blue (T6146-25G, Sigma Inc.) Exclusion Test. Additionally, LIVE/DEAD ${ }^{\circledR}$ Cell Viability Assays (cat. No L 7013, Life Technologies Corp.) were used according to the manufacturer instruction.

\section{Spermatogonia Stem Cell Colony forma-} tion assay

Thawed primary culture of collagen-nonebinding spermatogenic cells of tested condition was subjected to 40 min laminin selection as described previously $[10,17]$. Selected laminin binding population of cells was plated into the new laminin coated well of 48 well plate $(0.95$ $\mathrm{cm}^{2}$ ) in SG medium at cell densities ranging between $\sim 10^{4}$ to $\sim 5 \times 10^{4}$ cells/well. Cells were incubated at $36.5^{\circ} \mathrm{C}, 5 \% \mathrm{CO}_{2}$ for 24 hours or 6 days and supplemented with fresh SG medium every second day. After incubation for a designated time period cells were fixed with
$4 \%$ paraformaldehyde and labeled using antibodies to ZBTB16 and DAZL and Hoechst 33342 dye. Only double positive cells and interconnected clonal cell units were scored. Microphotographs were taken with IX70, Olympus fluorescence microscope (Olympus Inc.) equipped with Simple-PCI software (C-Imaging Systems, Compix, Cranberry Township, PA). The average numbers of type A spermatogonia (PLZF+, DAZL + ) and Hoechst 33342+ somatic testis cells (DAZL negative) per field were calculated ( $\mathrm{n}=3$ separate wells from 3 separate primary cultures/ condition).

\section{Immunocytochemistry}

The germ cells cultivated on laminin were fixed by $4 \%$ paraformaldehyde in $1 \mathrm{M}$ phosphate buffer ( $\mathrm{pH}$ 7.2) for $10 \mathrm{~min}$. After fixation the cells were washed twice with a PBS (PBS; Invitrogen Inc, cat no. 14040-182) and permeabilized with $0.1 \%(\mathrm{v} / \mathrm{v})$ Triton $\mathrm{X}-100$ in PBS. The cells were then washed twice with PBS and incubated in $1 \%(\mathrm{v} / \mathrm{v})$ solution of blocking reagent (Roche, Applied Biosystem) for 1 hour at $\sim 22-24^{\circ} \mathrm{C}$. The mouse anti-human ZBTB16 IgG (Calbiochem, cat no. OP128, clone ID 2A9) were diluted 1:500, the home prepared rabbit anti-DAZL-3 IgG [10] were diluted to $250 \mathrm{ng} / \mathrm{ml}$ in blocking reagent. After incubation with primary antibody, cells were washed with PBS and then incubated for $40 \mathrm{~min}$ at $\sim 22-24^{\circ} \mathrm{C}$ with goat anti-mouse AlexaFluor594 or goat anti-rabbit AlexaFluor488 secondary antibodies (Invitrogen, Inc) diluted to $5 \mu \mathrm{g} / \mathrm{ml}$ in PBS containing $5 \mu \mathrm{g} / \mathrm{ml}$ Hoechst 33342 dye (Molecular probes, cat no. H3570). After incubation with secondary antibodies the cells were washed with PBS and 
viewed using an inverted Olimpus IX70 microscope (Olympus, Inc.)

\section{Results and Discussion}

SG medium does not support the proliferation of somatic cells present in the collagen-nonbinding population of the primary culture and only stem cells can proliferate and make colonies in this medium. We speculated that direct selection of germ stem cells could be possible in SG medium without the preliminary laminin and gelatin selection steps. On average $3-3.6 \times 10^{6}$ cells/vial of collagen non-binding testis cells from mutant rat strains tgSBSlc35a $3^{\text {wt:gt, }}$ tgSB-Pan3wt:gt and tgSBZymnd $8^{\text {wt:gt }}$ were cryopreserved. The cells were thawed after $\sim 16-24$ months of cryopreservation. For the derivation of spermatogonial cell lines, two vials from each of the line were thawed, mixed together and then divided into two equal parts. One part of the recovered cells $\left(550 \times 10^{5}\right.$ cells for Pan $3,375 \times 10^{5}$ cells for Slcla35a, and $485 \times 10^{5}$ cells for Zmynd8) was cultured on laminin $\sim 40 \mathrm{~min}$ to positively select undifferentiated spermatogonia, which were then cultured overnight on gelatin in SG Medium to select out somatic cells, before plating on MEFs. The second equal part was plated directly onto MEFs (Fig. 1).

After the matrix selections we obtained approximately $9-15 \%$ of laminin-binding spermatogonia out of total recovered live cells. For SG selection all recovered live cells $(\sim 3.75-5.5$ $\times 10^{5}$ cells) were plated on MEFs. Growth rates for the cultures initiated under both conditions were analyzed over 6-7 passages (Fig. 2). The difference in the spermatogonia cell harvest between the two selection methods was significant at the first cell passage: SG medium selection resulted in $2-2.3$ times higher cell yield compared to usual matrix selection.

Applying SG medium selection, by passage 7 (or approximately in 80 days) we were able to grow up not less than $2.5 \times 10^{6}$ germ cells per line. Such quantity provided enough cells to prospectively transplant up to 4 rats/spermatogonial line with $\sim 3 \times 10^{5}$ cells/testis and transmit donor haplotypes to progeny by natural breeding.

This was confirmed with an additional spermatogonial line derived from tgSB-Gsg $11^{\text {tg:wt }}$

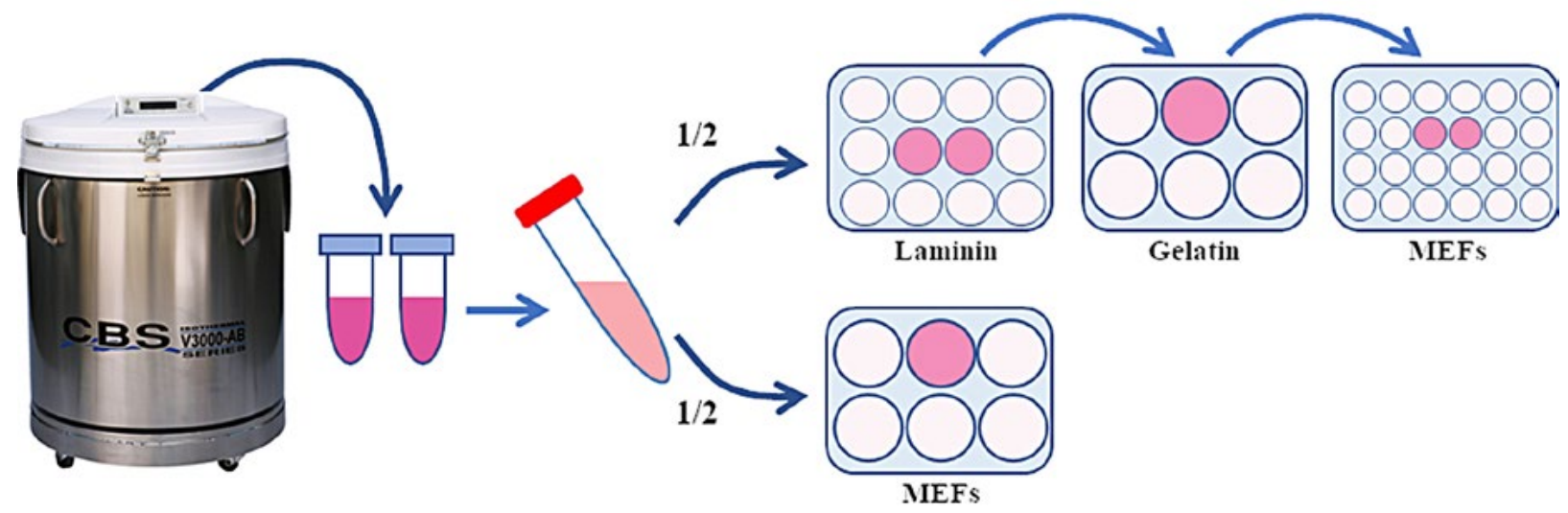

Fig. 1. Derivation of spermatogonial cultures from a frozen stock of cryopreserved collagen non-binding testis cells with and without selection on extracellular matrices. 

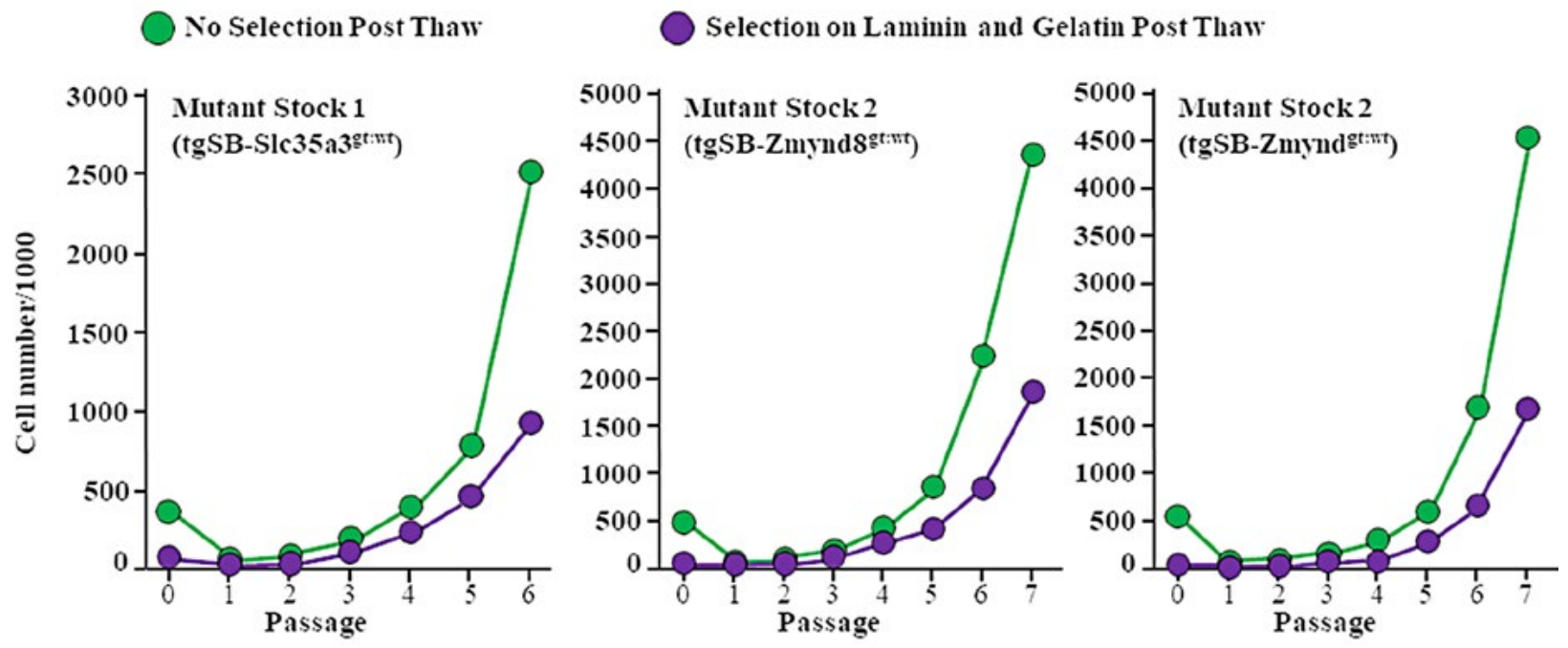

Fig. 2. Growth curves of spermatogonial cultures derived from 3 different Sleeping Beauty mutant rat strains (tgSB-

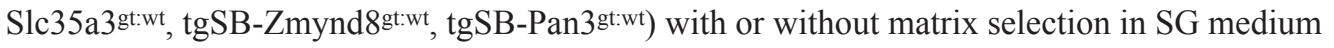

testis cells in the absence of matrix selection after cryostorage for $\sim 24$ months.

The cells containing the Tmx4, Slc35a3 and Gsg11 gene traps robustly expressed the tgGCS-EGFP transgene, which allowed clear detection of germ cells in culture (Fig. 3A), or during preliminary analyses of their development in recipient testes (Fig. 3B) [15]. The donor cell-derived $\mathrm{F} 1$ progeny transmitted their specific transgenes to F2 progeny at near Mendelian rates. Representative crosses between 2 F1 tgSB-Pan $3^{\text {tg:wt }}$ rats and 2 wildtype Sprague Dawley rats yielded $45 \%$ of heterozygotes for the Pan3 gene trap ( $\mathrm{n}=2$ litters, 31 F2 pups, one litter/breeder pair). Moreover, a pair of F1 tgSB-Gsg1 1t:wt breeders yielded $30 \%$ wildtype, $57 \%$ heterozygotes, $13 \%$ homozygotes for the Gsg11 gene trap ( $\mathrm{n}=3$ litters, $47 \mathrm{~F} 2$ pups).

Thus, applying SG medium selection for the recovery of cryopreserved germ cell we were able not only to simplify the procedure but also to minimize the cell loss during laminin-gelatin selection steps.

To further increase the number of cells for initiation of cell line we considered the improvement of cryopreservation itself. First, we set up to analyze the concentration of DMSO in the freezing medium as a commonly used intracellular cryoprotectant.

The effect of DMSO concentration in SG Freezing Medium was tested on collagen nonbinding fractions of seminiferous epithelium cells from 30 wildtype Sprague Dawley rats at 22 days of age/experiment ( $\mathrm{n}=3$ experiment). The isolated fractions of spermatogenic cells from each individual isolation were divided equally into 14 vials for cryopreservation in SG Freezing Medium containing 6, 8, 10, 12, $14,16,18 \%$ v/v DMSO (i.e. duplicate vials/ DMSO concentration). Approximately $2.8 \times 10^{6}$ viable cells were aliquoted/vial for freezing in $1 \mathrm{ml} \mathrm{SG}$ Freezing Medium containing 7 different concentrations of DMSO (Table). 

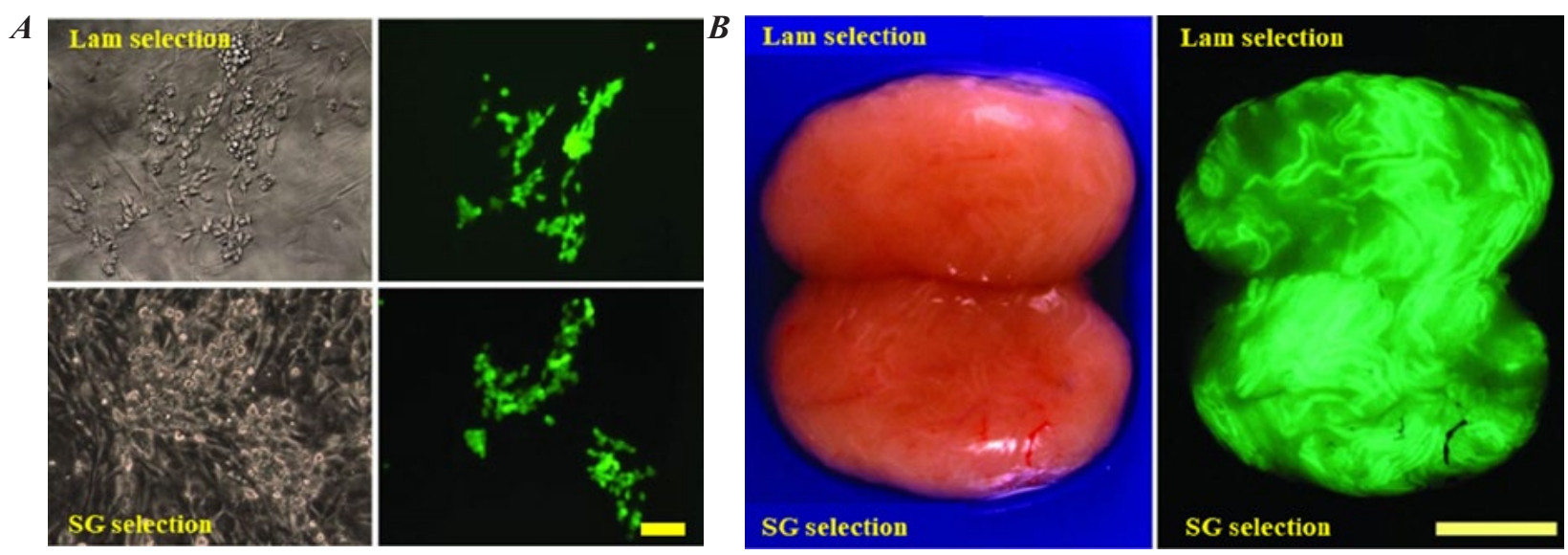

Fig. 3. $A$ - Appearance of Slc35a3 ${ }^{\text {gt:wt }}$ spermatogonial cultures on the tgGCS-EGFP rat background (green fluorescence) at P0 post-thaw with (Selection) or without (No Selection) selection for spermatogonia on extracellular matrices. Scale bar $=100 \mu \mathrm{m} . B$ - Testes of a single male rat transplanted contra-laterally with Slc35a3 ${ }^{\text {gt:wt }}$ spermatogonial cultures derived with (Selection) or without (No Selection) selection for spermatogonia on extracellular matrices, as shown in panel A. Scale Bar $=0.5 \mathrm{~cm}$.

One vial of cells frozen at each DMSO concentration/experiment was thawed three months after cryopreservation to record the number of viable cells. The second vial of cells frozen at each DMSO concentration from each experiment was thawed and analyzed similarly after cryopreservation for 14 months. The amounts of type A spermatogonia and somatic testis cells and germ cell colonies recovered from each vial were scored on day 6 after culturing on laminin matrix in SG medium (see Spermatogonial Colony Forming Assay).

The cells preserved in SG Freezing Medium containing $8 \%$ of DMSO consistently demonstrated the highest viability post-thaw at their respective 3 and 14 months time points $(56.4 \pm 2.6 \%$ and $54.4 \pm 2.5 \%)$. Post-thaw the percent viable cells dropped by $\sim 6 \%$ after recovery from their respective, 3 and 14 months time points containing either $6 \%$ or $10 \%$ DMSO (Fig. 4A). After estimating cell viability post-thaw, the cells from each condition were cultured on laminin for 6 days in SG medium to score relative numbers of the surviving spermatogonia (DAZL+, PLZF+) and somatic (DAZL-) testis cells. The highest numbers of type A spermatogonia (Fig. 4B) and colonies of type A spermatogonia (Table) were observed in the cultures initiated from stocks preserved in SG Freezing Medium containing $8 \%$ of DMSO.

The spermatogonial colonies developed from $\sim 0.015 \%$ of the freshly isolated cells were cryopreserved using $8 \%$ DMSO (i.e. $1 / 15,000$ testis cells frozen). Ratios of spermatogonia (PLZF+, DAZL+) to somatic testis cells (PLZF-, DAZL-) were also the highest $(\sim 1: 5)$ in 6 day cultures initiated on laminin following recovery from SG Freezing Medium (Table). The germ cells consisted of A-single spermatogonia and syncytia of A-paired and A-aligned spermatogonial syncytia comprising up to 18 cells (Table).

Maximal numbers of A-single spermatogonia were detected in the cultures initially pre- 
Table. Recovery of germline and Somatic Testis Cell after Cryostorage in SG Freezing Medium and Culture on Laminin

\begin{tabular}{|c|c|c|c|c|c|c|c|}
\hline$\%$ DMSO in SG Medium (v/v) & 6 & 8 & 10 & 12 & 14 & 16 & 18 \\
\hline Viable Cells Frozen $\left(\mathrm{x} 10^{6}\right)^{*}$ & $2.82 \pm 0.1$ & $2.82 \pm 0.1$ & $2.82 \pm 0.1$ & $2.82 \pm 0.1$ & $2.82 \pm 0.1$ & $2.82 \pm 0.1$ & $2.82 \pm 0.1$ \\
\hline$\%$ Viability Post Thaw & $48 \pm 3.2$ & $54 \pm 2.5$ & $47 \pm 2.6$ & $39 \pm 2.2$ & $27 \pm 3.4$ & $20 \pm 2.7$ & $15 \pm 2.3$ \\
\hline $\begin{array}{l}\text { Cells Recovered from Laminin } \\
\left(\times 10^{3}\right)\end{array}$ & $39 \pm 4.9$ & $48 \pm 2.1$ & $40 \pm 1.2$ & $31.7 \pm 3.8$ & $22 \pm 2.1$ & $16.3 \pm 2.3$ & $9.7 \pm 0.33$ \\
\hline $\begin{array}{l}\text { DAZL/PLZF+ Cells D6 } \\
\text { Laminin** }\end{array}$ & $1032 \pm 59$ & $1285 \pm 77$ & $1123 \pm 59$ & $813 \pm 68$ & $532 \pm 31$ & $223 \pm 46$ & $108 \pm 85$ \\
\hline $\begin{array}{l}\text { DAZL/PLZF+ Colonies D6 } \\
\text { Laminin** }\end{array}$ & $364 \pm 22$ & $423 \pm 20$ & $387 \pm 17$ & $294 \pm 15$ & $210 \pm 7.9$ & $94 \pm 6.9$ & $53 \pm 3.5$ \\
\hline $\begin{array}{l}\text { DAZL/PLZF+ Cells D6 } \\
\text { Laminin (\%)** }\end{array}$ & 0.037 & 0.046 & 0.04 & 0.029 & 0.019 & 0.008 & 0.004 \\
\hline $\begin{array}{l}\text { DAZL/PLZF+ Colonies D6 } \\
\text { Laminin** }\end{array}$ & 0.013 & 0.015 & 0.014 & 0.01 & 0.0075 & 0.0033 & 0.002 \\
\hline $\begin{array}{l}\text { Somatic: Germ Cell D6 } \\
\text { Laminin** }\end{array}$ & $85: 15$ & $82: 18$ & $84: 16$ & $88: 12$ & $92: 8.5$ & $95: 5.2$ & $97: 3.2$ \\
\hline
\end{tabular}

served in SG Freezing Medium containing 6, 8 , and $10 \%$ of DMSO (Fig. 5).

Numbers of A-single spermatogonia dropped as a function of increasing DMSO concentrations tested from 12-18\%. Similar trends were observed for A-pair and A-aligned spermatogonia (Fig. 5).

It was demonstrated that an ability to derive spermatogonial lines from collagen non-binding testis cells is more efficient after cryopreservation (i.e. without added matrix selection steps). It is especially intriguing because it raises questions if similar methods would facilitate the derivation of spermatogonial lines from other species, including primates. It is interesting that freshly isolated fractions of collagen non-binding testis cells are composed of $\sim 90 \%$ of spermatogenic cells and $\sim 10 \%$ of somatic testis cells [10]. More than $95 \%$ of spermatogonial stem cells in the collagen nonbinding testis cell fraction can be isolated by selection on laminin, which yields $>90 \%$ of type A spermatogonia and $\sim 4$ of somatic testis cells. However, following cryopreservation of the collagen non-binding testis cell fraction, only $\sim 10-20 \%$ of the total cell population survives (Table). Because we observed predominantly undifferentiated type A spermatogonia $\left(\mathrm{PLZF}^{+}, \mathrm{DAZL}^{+}\right)$and somatic cells (DAZL-) following cryopreservation and overnight culture of collagen non-binding testis cells (Table). Moreover, when cultured for 1 to 2 weeks after plating directly on irradiated MEFs post-thaw, over-growth of somatic testis cells in culture was not problematic for deriving spermatogonial lines in the serum-free SG Medium (Fig. 2). Thus, considering the potential translational relevance of these find- 

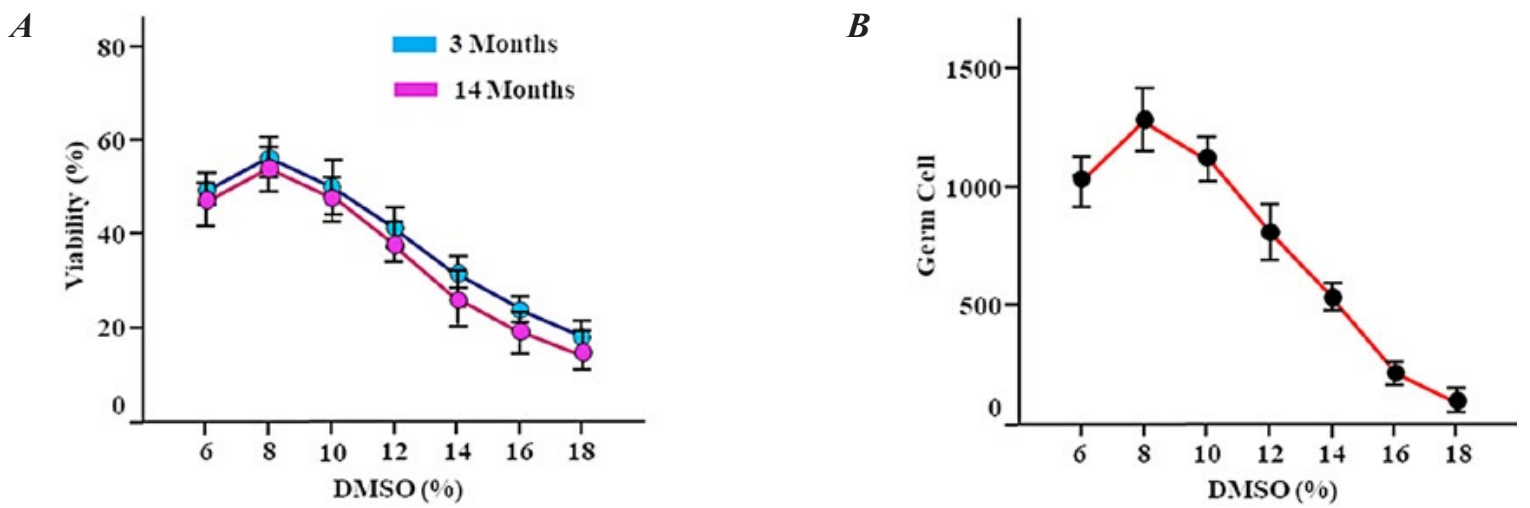

Fig. 4. A. Viability of freshly isolated collagen non-binding testis cells after cryopreservation for 3 and 14 months in $1 \mathrm{ml} \mathrm{SG}$ Freezing Medium supplemented with different concentrations of DMSO. Mean \pm S.E.M., $\mathrm{n}=3$ three primary cultures/time point. B. Numbers of DAZL+, PLZF+ Germ Cells (i.e. type A spermatogonia) counted on day 6 post-thaw after culturing in SG Medium on laminin following 14 months of cryopreservation in SG Freezing Medium containing the indicated DMSO concentrations. Mean \pm S.E.M., $n=3$ three primary cultures.

ings for clinical application, the understanding propagation of spermatogonial lines from biof testis cell fate in culture post-thaw could opsies to rescue infertility in men with hypoprovide a key insight needed for successful spermatogenesis.

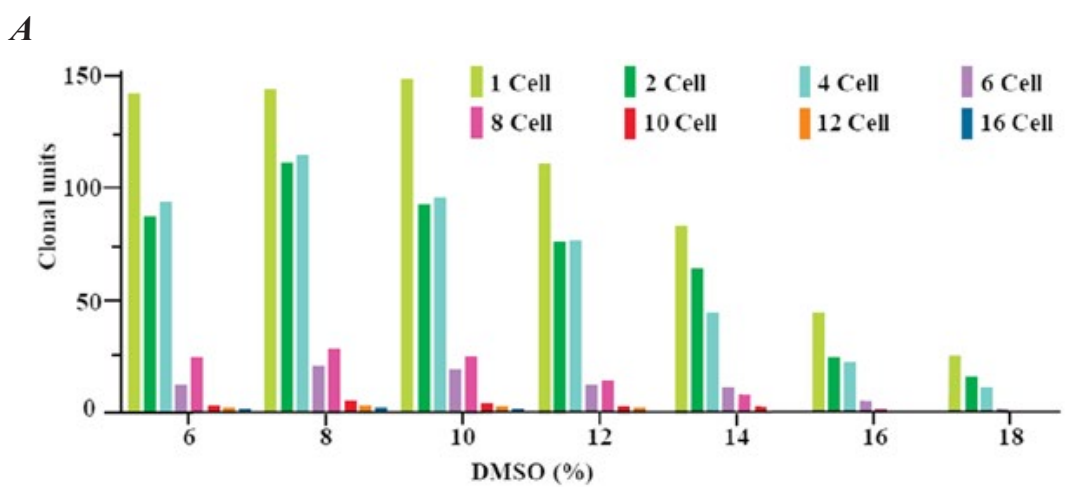

$\boldsymbol{B}$

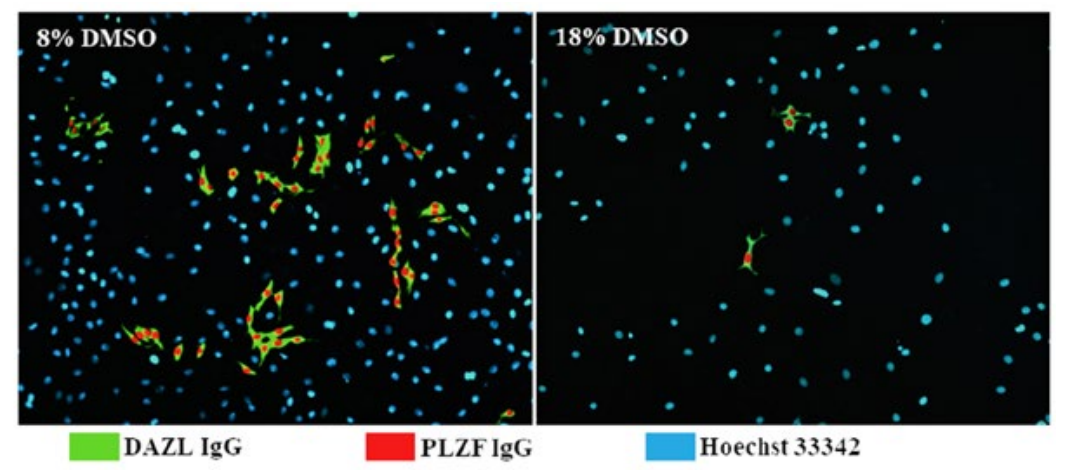

Fig. 5. $A-$ Clonal units of type A spermatogonia comprising different numbers of cells scored in cultures analyzed under conditions described in panel C. $B$ - Representative images of rat testis cell cultures analyzed on day 6 following labeling with antibodies to PLZF (red) and DAZL (green), and with Hoechst 33342 dye (blue). Scale bar $=100 \mu \mathrm{m}$. 


\section{Conclusions}

In the present work we developed and optimized recovery and storage of spermatogonial stem cells, which could be consistently derived from freshly thawed stocks of collagen nonbinding testis cells cryopreserved in SG. Our data suggest that the $8 \% \mathrm{DMSO}$ is the most effective concentration of the cryoprotectant. In summary, efficient isolation, cryopreservation and recovery of spermatogonial stem cells provide a foundation for research on spermatogenesis and transgenesis in rodents, and will likely impact our ability to preserve fertility in other species, including humans [13, 17$]$.

\section{Acknowledgments}

The authors gratefully acknowledge the financial support of this study by the UTSouthwestern Medical Center and colleagues: Jerardo Medrano for taking care of animals and help with genotyping and Dr. Hamra for help with spermatogonia transplantation procedure.

\section{REFERENCES}

1. Wu X, Goodyear SM, Abramowitz LK, Bartolomei MS, Tobias JW, Avarbock MR, Brinster RL. Fertile offspring derived from mouse spermatogonial stem cells cryopreserved for more than 14 years. Hum Reprod. 2012;27(5):1249-59.

2. Liu S, Tang Z, Xiong T, Tang $W$. Isolation and characterization of human spermatogonial stem cells. Reprod Biol Endocrinol. 2011;9:141.

3. Syvyk T, Syvyk A. Customized transgenesis via modification of spermatogonial stem cells. Journal of microbiology, biotechnology and food sciences. 2018; 7 (5) 475-479.

4. Mays-Hoopes LL, Bolen J, Riggs AD, Singer-Sam J. Preparation of spermatogonia, spermatocytes, and round spermatids for analysis of gene expression using fluorescence-activated cell sorting. Biol Reprod. 1995;53(5):1003-11.
5. Gassei K, Ehmcke J, Schlatt S. Efficient enrichment of undifferentiated GFR alpha 1+ spermatogonia from immature rat testis by magnetic activated cell sorting. Cell Tissue Res. 2009;337(1):177-83.

6. Kanatsu-Shinohara M, Morimoto H, Shinohara T. enrichment of mouse spermatogonial stem cells by the stem cell dye CDy1. Biol Reprod. 2016;94(1):13.

7. Kubota H, Brinster RL. Culture of rodent spermatogonial stem cells, male germline stem cells of the postnatal animal. Methods Cell Biol. 2008;86:59-84.

8. Kanatsu-Shinohara M, Inoue K, Ogonuki N, Morimoto H, Ogura A, Shinohara T. Serum- and feederfree culture of mouse germline stem cells. Biol Reprod. 2011;84(1):97-105.

9. Wu Z, Falciatori I, Molyneux LA, Richardson TE, Chapman KM, Hamra FK. Spermatogonial culture medium: an effective and efficient nutrient mixture for culturing rat spermatogonial stem cells. Biol Reprod. 2009;81(1):77-86.

10. Chapman KM, Saidley-Alsaadi D, Syvyk AE, Shirley JR, Thompson LM, Hamra FK. Spermatogonial stem cell mediated gene transfer. Transgenic technology, Eds. Shirley Springer Protocols handbooks springer protocols handbooks;2011. 237-266 p.

11. Ivics Z, Izsvák Z, Chapman KM, Hamra FK. Sleeping Beauty transposon mutagenesis of the rat genome in spermatogonial stem cells. Methods. 2011;53(4):356-65.

12. Goodyear S, Brinster R. Spermatogonial stem cell transplantation to the testis. Cold Spring Harb Protoc. 2017;2017(4):pdb.prot094235.

13. Syvyk A, Djachenko L, Syvyk T. Transgenesis through the spermatogonia stem cells in the animals and prospects of its application in Bilotserkiva NAU. Collection of scientific works of Bila Tserkva NAU. 2017;1(134), 5-12.

14. Stacey GN, Masters JR. Cryopreservation and banking of mammalian cell lines. Nat Protoc. 2008;3(12): 1981-9.

15. Cronkhite JT, Norlander C, Furth JK, Levan G, Garbers DL, Hammer RE. Male and female germline specific expression of an EGFP reporter gene in a unique strain of transgenic rats. Dev Biol. 2005;284(1):171-83.

16. Pegg DE. Principles of cryopreservation. Methods Mol Biol. 2015;1257:3-19. 
17. Mirzapour T, Movahedin M, Tengku Ibrahim TA, Haron AW, Nowroozi MR. Evaluation of the effects of cryopreservation on viability, proliferation and colony formation of human spermatogonial stem cells in vitro culture. Andrologia. 2013;45(1):26-34.

\section{Удосконалене відновлення і кріозбереження сперматогоній щурів для створення банку статевих стовбурових клітин}

Т. Л. Сивик, Л. С. Дяченко, А. С. Сивик

Ціль. Оптимізувати кріоконсервуючий розчин для сперматогонії і процедуру їі відновлення. Методи. ПЛР, Тест на виживання клітин, Тест на формування сперматогональних колоний, імуноцитохімія, кріоконсервація і розморожування сперматогонії. Результати. Три мутовані сперматогональні стовбурові клітинні лінії Спляча Красуня після 17-24 місяців кріоконсервації були відновлені двома методами: традиційним - із застосуванням ламінінової селекції і новим методом селекції ССК у живильному середовищі на мишачих ембріональних фібробластах. Мутовані лінії ССК, відновлені двома методами, трансплантували у сім'яники самців-реципієнтів. Були отримані трансгенні нащадки. Ми вдосконалили концентрацію ДМСО в розчині для заморожування ліній ССК. Висновки. Після виділення ССК із сім'яників щура і тривалого кріозбереження, оптимізована процедура відновлення їх у живильному середовищі дозволяє успішно отримувати трансгенні тварини із банку мутованих ліній ССК. Наші результати доводять доцільність включення 8 \% ДМСО до складу живильного середовища для ССК з метою кріоконсервування.

К л юч о в і с с л о в а: сперматогональні стовбурові клітини, мутовані лінії, ламінінова селекція, кріоконсервація.

\section{Усовершенствованное восстановление и криосохранение сперматогоний крыс для создания банка половых стволовых клеток}

\author{
Т. Л. Сывык, Л. С. Дяченко, А. Е. Сывык
}

Цель. Оптимизировать раствор для криоконсервации сперматогонии и процедуру её восстановления. Методы. ПЦР, Тест на выживаемость клеток, Тест на формирование сперматогональных колоний, иммуноцитохимия, криоконсервация и размораживание сперматогонии. Результаты. Три мутированные сперматогональные стволовые клеточные линии Спящая Красавица после 17-24 месяцев криоконсервации были восстановлены двумя методами: традиционным - с применением ламининовой селекции и новым методом селекции сперматогональных стволовых клеток (ССК) в питательной среде на мышиных эмбриональных фибробластах. Мутированные линии ССК, восстановленные двумя способами, трансплантировали в семянники самцов-реципиентов. Было получено трансгенное потомство. Мы усовершенствовали концентрацию диметилсульфоксида (ДМСО) в растворе для замораживания линий ССК. Выводы. После выделения ССК из семянников крыс и длительного криосохранения, оптимизированная процедура восстановления их в питательной среде позволяет успешно получать трансгенных животных из банка мутированных линий ССК. Наши результаты доказывают целесообразность включения 8 \% ДМСО в состав питательной среды для ССК с целью криоконсервации.

К л юч е в ы е с л о в а: сперматогональные стволовые клетки, мутированные линии, ламининовая селекция, криоконсервация.

Received 08.03.2018 